\title{
'I never really left the university:' continuity amongst male academics in the transition from work to retirement
}

Article

Accepted Version

Creative Commons: Attribution-Noncommercial-No Derivative Works 4.0

Rowson, T. S. and Phillipson, C. (2020) 'I never really left the university:' continuity amongst male academics in the transition from work to retirement. Journal of Aging Studies, 53. 100853. ISSN 0890-4065 doi:

https://doi.org/10.1016/j.jaging.2020.100853 Available at https://centaur.reading.ac.uk/90704/

It is advisable to refer to the publisher's version if you intend to cite from the work. See Guidance on citing.

To link to this article DOI: http://dx.doi.org/10.1016/j.jaging.2020.100853

Publisher: Elsevier

All outputs in CentAUR are protected by Intellectual Property Rights law, including copyright law. Copyright and IPR is retained by the creators or other copyright holders. Terms and conditions for use of this material are defined in the End User Agreement.

www.reading.ac.uk/centaur 
Central Archive at the University of Reading

Reading's research outputs online 
Title: 'I never really left the university:' continuity amongst male academics in the transition from work to retirement. 


\section{Abstract}

This study investigates the transition to retirement of male academics. It applies approaches drawn from Cumulative Advantage and Disadvantage (CAD) principles to expand Continuity theory by examining evidence for continuity and inequalities in the lifestyles of the respondents. Biographical-Narrative interviews with 20 retired academics in Brazil and the United Kingdom were conducted and analysed using Thematic Analysis. An exploration of the same occupational group in different cultural and social contexts was carried out to capture a diversity of CAD influences on retirement outcomes. The experience of continuity was individualised to each participant due to their unique combination of advantages, and their subjective interpretation of their experiences. Cumulative processes identified in this study related to (1) occupational roles played in their career; and (2) organisational level policies and practices for retirement. At the level of individual retired men, cultural and social context factors were not perceived as influential in the achievement of continuity in retirement. Continuity theory is still supported, but alone offers limited explanations of the diversity of experiences in the transition to retirement of male academics. A consideration of the role of cumulative processes and systemic dynamics, including how individuals respond to their experiences in retirement, shows how these different factors interact and affect retirement and ageing. Further studies should investigate the processes identified with other occupations, as well as women and minority groups.

Keywords: Continuity Theory, Cumulative Advantage/Disadvantage, Academics, Retirement, Cross-cultural, Biographical-Narrative 


\section{Introduction}

The transition from work to retirement may affect individuals in a variety of ways, notably in respect of resources, relationships, and social status (von Bonstoff \& Ilmarinen, 2012). The process of withdrawal from employment has itself shifted from being a predictable and standardised event, to one viewed as both unpredictable and individualised (Lain, Airey, Loretto \& Vickerstaff, 2020; Phillipson, 2002; Vickerstaff \& Cox, 2005). Moreover, retirement is increasingly experienced as a dynamic process, with increasing numbers of workers moving in and out of the workforce at different points across the life course (Wand \& Schultz, 2010). This article focuses on the process of retirement as a major life transition, one involving a redefinition of tasks, relationships, and self-image (Damman, Henkens \& Kalmijn, 2015). Retirement involves, it is argued, both subjective and objective changes (Moen, 1996), representing a mix of continuities and discontinuities in lifestyles (Phillipson, 2019). To examine this issue, this paper explores the experience of continuity in the transition to retirement of male academics in the United Kingdom [UK] and Brazil. The paper draws on cumulative advantage and disadvantage (CAD) theory (Crystal, Shea \& Reyes, 2017; Dannefer, 2003; 2018), as a way of explaining potential inequalities influencing the type of work and retirement transitions experienced by this group.

\section{Theoretical Background}

An important perspective in social gerontology has been that of continuity theory, as developed by Robert Atchley (1999). This approach took the view that, as part of the adaptation to growing older, the individual would attempt to maintain stability in attitudes and activities developed over the lifecourse. The theory suggests that during transitions, such as those from work to retirement, the individual will strive to preserve the habits, experiences and lifestyle acquired over a lifetime, as way of maintaining a coherent sense of self. Continuity theory 
builds on ideas drawn from personal construct psychology (Kelly, 1955), suggesting that individuals develop theories about themselves through the feedback of significant others. Over time, these are consolidated into generalisations which come to form the core of a person's identity (Atchley, 1989; Whitbourne, 1986). From the point of midlife, lifestyles, values and beliefs will be firmly established, providing the basis for continuity in later periods of transition. Atchley argues that: 'Once the individual has developed a strong sense of self, close personal relationships and a relatively enduring lifestyle, continuity theory can be expected to come into play in explaining their decision-making process concerning adaptation to life' (Atchley, 1999:6).

Atchley (1999) draws a distinction between 'internal' and 'external' continuities which, he suggests, are experienced at psychological, behavioural and sociological levels, and which serve to integrate different elements of a person's life. Internal continuity is perceived by the individual in relation to remembered inner structures, such as personal constructs, together with the structure of ideas, temperament, experiences, preferences, dispositions, and skills. External continuity is defined in terms of remembered structures of activities, physical and social environments and relationships (Atchley, 1989). The implications of this argument are that even though others can observe continuity, only the individual him- or herself can validate whether it has been achieved. This means that whether individuals experience continuity or not is subjective, dependent upon how individuals interpret their experiences 'here and now' as being coherent with their own internal frameworks.

When certain patterns are no longer possible, due to ill health, disability or financial circumstances, discontinuity is likely to be experienced, potentially affecting the individual's adjustment to ageing. In these circumstances, individuals tend to concentrate their efforts on maintaining continuity in domains of perceived strengths (Atchley, 1989). Atchley's arguments find support in psychological models such as: selection, optimization and compensation (SOC) 
(Baltes, 1997). Whether motivated by loss or choice, individuals who select life domains that are rewarding and successfully performed within their available resources, tend to adjust better to age-related changes (Baltes, 1997), albeit with the possibility of lower expectations (Brandstadler \& Greve, 1994).

Critics of continuity theory highlight the extent to which economic, social and political factors may be disruptive of life trajectories (Achenbaum, 2009; Phillipson, 2013), and that midlife is neither a stable nor linear transition (Earl \& Taylor, 2017; Katz, 2020). However, Atchley (1989) argues that the theory does not assume sameness throughout life, rather, a gradual and coherent evolution of an individuals' biography and sense of self. This argument reflects the origins of the theory within personal construct psychology, with its emphasis on the use of internal frameworks to evaluate life experiences. Such frameworks, or constructs, are constantly evolving as individuals make sense of their experiences in a process called 'revalidation' (Kelly, 1980). Discontinuity tends to be experienced when personal constructs and identities are challenged, and where they no longer represent the issues and situations which individuals face in their lives (Atchley, 1989).

However, it remains the case that continuity theory does not explicitly address the influence of systemic forces, especially regards how life patterns are constructed and crystallised over time. Studies on inequality in later life explore continuities in terms of the impact of differences in relation to areas such as education, health status, and financial resources (Atkinson, 2015; Crystal et al., 2017; Dannefer, 2003; Ferraro \& Morton, 2018). Building on the idea of cumulative advantage, and the Matthew effect (Merton, 1968, 1988), Dannefer (2003:327), for example, defined cumulative disadvantage and advantage theory (CAD) as 'the systemic tendency for interindividual divergence in a given characteristic (e.g., money, health, or status) with the passage of time'. This approach presents growing old as a collective process of intra-cohort stratification, as economic and social processes allow the 
accumulation of advantages over the life course for some, but the accretion of disadvantages for others (Crystal et al., 2017; Dannefer, 2018).

Inequality is unevenly distributed at all points of the life course (Atkinson, 2015). This is illustrated by the extent to which gender impacts retirement outcomes, with women more likely to experience career interruptions, discrimination within the workplace, and inequalities associated with pensions and workplace benefits (Lain et al., 2020; Ní Léime, 2017; Wildman, 2019). Dannefer (2018) argues that cumulative processes are an influential force at macro-, but also at meso- and micro-levels. Such meso and micro processes might be overlooked at a population level, despite their potentially important contribution in producing inequalities in later life (Dannefer, 2003). For example, micro-processes, such as opportunities for career progression, development and promotion, and meso-processes, generated by organisationallevel structures, will also influence transitions through the life course (Field, Burke \& Cooper, 2013).

Cumulative processes are likely to have an important influence on the experience of continuity or discontinuity. Thus, drawing on the CAD approach allows us to better understand how patterns of continuity are formed and experienced in later life, and how the dynamics between accumulation of resources and risks (Ferraro \& Morton, 2018) might influence retirement outcomes. This perspective relates to social context and personal circumstances, and directly addresses some of the criticisms of continuity theory. However, CAD and continuity theory are based on different assumptions, creating tension in the articulation of these in a single study. The objective and systemic focus of CAD is in contrast to the subjective nature of continuity theory, despite Atchley's (1999) use of objective measures to report continuity. The assumptions regarding the dynamics of social structures and agency are also divergent. Yet, the combination of these theories have the potential to integrate individual perspectives and systemic forces, with the potential to enhance understanding of late life experiences such 
as retirement (Ferraro \& Morton, 2018; Schafer et al., 2011). From this review of the theoretical background, the next section considers the specific example of male academics in retirement, summarising first of all the existing literature in this area.

\section{Academics and retirement}

This article focuses on the transition to retirement of university male academics, exploring both their experience of continuity in retirement, together with the potential influence of cumulative processes. Academics have been described as a distinct occupational group due to the nature of their career (Sugar, Pruitt, Anstee \& Harris, 2005; Taylor, 1999), with the possibility of their knowledge, skills and experiences providing an illustration of continuity in later life (Danson \& Gilmore, 2012). As in other sectors, schemes to reduce staff numbers (in countries such as the UK) have pushed many academics into early retirement (Danson \& Gilmore, 2012; Tizard \& Owen, 2001). Despite this, the environment associated with academic life has traditionally placed a high value on age and experience (Danson \& Gilmore, 2012). Thus, it is not uncommon for senior academics to take formal and informal positions following their departure from paid, full-time employment (Cahill, Pettigrew, Robinson \& Galvin, 2019; Danson \& Gilmore, 2012; Tizard \& Owen, 2001; Veiga, 2007), or to serve in advisory positions in academic as well as non-academic settings.

In terms of career development, following an extended period of training (Sugar et al., 2005; Tizard \& Owen, 2001), academics may experience a degree of continuity in the pursuit of particular lines of research, the development of teaching expertise, and the acquisition of a reputation within the profession (Taylor, 1999). Taylor argues that: 'It is through this essentially linear progression that contributions to their institution will be recognised and rewarded, [and] that an academic's career will advance' (1999:40). The continuity aspect of an academic career, as pointed out by Taylor (1999), can also be observed in retirement as 
suggested by previous studies (Cahill et al., 2019; Danson \& Gilmore, 2012; Thody, 2011; Tizard \& Owen, 2001; Veiga, 2007).

Many academics continue to work in retirement, maintaining an occupational identity whilst adjusting to retirement at the same time (Cahill et al., 2019). Tizard and Owen (2001) suggest that experiences of continuity are often related to academic activities and occupational visibility before retirement. Regardless of occupational prestige, not all of those retiring will want to continue to practice as an academic (Davies \& Jenkins, 2013; Thody, 2011), and institutions vary greatly in the opportunities provided to academic staff (Thody, 2011; Tizard, 2004). This suggests there is likely to be considerable diversity in the transition to retirement amongst academics, together with variations in the experience of continuity and discontinuity (Cahill et al., 2019; Davies \& Jenkins, 2013; Thody, 2011; Tizard \& Owen, 2001).

This article aims to contribute to the literature on the experience of continuity in the transition to retirement, in three main ways. Firstly, the role of CAD processes will be considered from the perspective of the individual. Secondly, how people make sense of their experience of internal and external continuity will be examined. Third, these issues will be explored through the experiences of male academics in Brazil and the UK, countries with contrasting cultures and social structures.

Academics already enjoy several advantages, both in respect of educational background and work conditions, and, in the case of the sample chosen, access to an adequate retirement pension. Academic careers are relatively similar in Brazil and the UK, at least in the case of individuals with permanent contracts. Academic staff are expected to be involved in a mixture of teaching, research and administrative roles (Collini, 2012; Halsey, 2004; Schwartzman \& Balbachevsky, 1997). Although national social structures may influence the experiences of Brazil and UK academics in retirement (Disney \& Whitehouse, 2003), there is evidence that 
retired academics report similar experiences in both countries (Tizard \& Owen, 2001; Veiga, 2007).

\section{Methodology}

The extent to which individuals experience continuity can only be studied in retrospect, with individuals making an assessment of their current circumstances compared with situations in the past (Atchley, 1989). Hence, this study follows the biographical narrative approach developed by Rosenthal (2005), and Holloway and Jefferson (2000). Biographical narrative is especially useful in exploring how ageing is experienced and understood by individuals (Roberts, 2002). Riessman (1993) highlights that experiences and interpretations cannot be accessed directly, but through the stories which people tell about themselves and their lives. Schafer et al. (2011:1081) argue that disadvantages derived from concrete social conditions are embedded in these personal narratives, through a process of 'biographical structuration'. Therefore, the use of biographical narrative approach enables us to take the perspectives of individuals to explore the role of cumulative processes in their experience of continuity.

The biographical narrative interview schedule was composed of a single life story 'thematic focused' question (Rosenthal, 2005:51), 'Can you please tell me your life story from when you first started to think about your career, starting as far back as you like. All the events and experiences which were important for you, personally, up to now. Please start wherever you like and take as much time as you want.' This question was designed to encourage participants' narratives, using their own internal logic. To help them reflect further on their careers and retirement experiences, prompts were included in the schedule and introduced if necessary, after the main narrative was completed. In addition, demographic questions were included at the end of each interview, for example, age, marital status, health status, job title before retirement, and years spent in retirement. 
The interviews were conducted in the language of each country and were voice-recorded. Written permission was given by each participant for the recording. The interviews varied in length, from 30 to around 120 minutes. The recordings were later transcribed verbatim, and those conducted in Brazil translated into English by the first author who is proficient in both languages. To ensure the integrity of the data, these translations were additionally checked for accuracy by a professional interpreter who is a Brazilian Portuguese native speaker.

The transcripts were loaded to $\mathrm{N}$-vivo 11 to be subsequently analysed. The information from each country was inductively analysed separately using the thematic analysis method (Braun \& Clarke, 2006), before having the findings compared and contrasted. Mindjet mindmapping software was also used to consolidate the themes and subthemes generated from both samples. At this stage, the significance of the themes was explored in relation to the research question and theoretical background of this study (Boyatzis, 1998). To ensure trustworthiness (Morrow, 2005), the data was analysed by the first author, and reviewed by the second author and another member of the research team. In addition, a reflexivity diary was kept during the course of the study, aiming to challenge personal biases and assumptions that might have impacted the interpretation of findings.

Retirement can refer to an event, a process, a status, a role, or a phase of life (Kohli \& Rein, 1991), and it can have its meaning attached to different objective and subjective criteria, such as work, income and pension receipt as well as the self-assessment of individuals (Ekerdt \& DeViney, 1990; Kohli \& Rein, 1991). As retirement serves many purposes, it invariably means different things for different people (Atchley, 2000; Künemund \& Kolland, 2007). Considering the ambiguity in the meaning of retirement, for this study it was defined as in receipt of retirement pension. Therefore, some of the sample may be still employed as well as receiving a retirement pension, particularly considering the early retirement practices noted in previous literature on the retirement of academics in the UK (Danson \& Gilmore, 2012; Tizard, 
2001) and Brazil (Veiga, 2007). It is also important to note that the UK sample retired before the abolishment of mandatory retirement age of 65 years. In Brazil, universities cease the employment of academics over the age of 70 years old, this is referred to as compulsory retirement. Some institutions, however, offer Emeritus positions beyond that age.

The men in this study had been retired for between one and six years, a period considered appropriate for examining patterns of continuity between work and retirement (see further Tizard \& Owen, 2001). Limiting the sample to men in the age group selected reflects the historic and continuing dominance of men in academic institutions. Gender is a significant factor contributing to inequalities in later life, reflecting discrimination within the workplace, the impact of caring responsibilities, and limited access to occupational pensions (Ní Léime, 2017; Wildman, 2019). The historical discrimination women have experienced in academic settings persists (Brooks, 1997), reducing opportunities for career progression, and consequently continuity in retirement (Schwartzman, 1998; Tizard \& Owen, 2001). The underrepresentation of women in academia (Catalyst, 2020; European Commission, 2012; University and College Union, 2013) is a manifestation of these disadvantages.

For the recruitment of samples in Brazil and the UK, two strategies were used: invitations to participate in the study in academic-related publications and use of the snowballing technique through Human Resources departments (or faculties) from various universities and universities' alumni groups. The selection of participants included men from different types of institution. In the UK, these were universities with different pension schemes, linked to when different institutions were awarded university status. In Brazil, these were state and non-state-owned universities, which have different pension schemes and employment rules. Their ages ranged from 56 to 76 years old. 
Names in this article have been changed to ensure anonymity. The participants job title at the time of retirement is provided next to quotes from the interview.

\section{Table 1: Sample}

\section{Findings}

All of the men reported experiencing occupational-related continuity in retirement, although the amount of formal continuity tended to decline both with age, and as they disengaged from their university. As participants reflected on their biographies and careers, they commented on how their contexts, career choices, roles and disciplines, influenced the kind of opportunities available to them in the transition to retirement. Their comments illustrate, as will be argued, the influence of both micro and meso-level cumulative processes. Factors identified by the participants were grouped into three interlinked themes: contextual factors, career-related advantages, and desire for continuity. In the accounts given by participants, continuity takes many forms, reflecting its subjective nature.

\section{Contextual factors}

Differences at the institutional levels emerged as being the most salient factor influencing the experience of continuity in retirement, overshadowing any evidence of social and contextual differences (Disney \& Whitehouse, 2003). The policies and practices of each institution with regard to retirement age, possible roles or titles for retired staff (e.g. Emeriti, Fellow), shaped participants' formal opportunities for continued engagement in both countries. For the UK, the diversity of policies and practices in retirement has been noted in research by Tizard (2004). Rules governing pension schemes, combined with the institutions' willingness to offer employment beyond retirement, also influenced opportunities:

I actually retired at 59 years and 11 months. What that allows you to do is to draw your pension but also to continue working, otherwise I think the rule is that if you retire after 
60 you're allowed to continue working for a university, but you're not allowed to earn any more than your last salary (Mathew, Professor, retired 2 years, UK).

I am retired through the state pension. The rules of the state pension allow you to continue working for the same employer, this is not illegal. I know that there was a time they wanted to prevent retired people from being employed. But that never materialised; there are a lot of retired academics still working here. (Alberto, Adjunct, retired 2 years, Brazil)

Contextual-related advantages, related to pension rules and institution-specific policies and practices in retirement, created the conditions shaping the extent of continuity from work to retirement. However, they do not in themselves explain different retirement experiences. Instead, they amplify or diminish the influence of career-related advantages in the transition from work to retirement.

\section{Career-related advantages}

Advantages accruing from the individual's career, reflects the extent to which individual circumstances related to job roles, activities, titles or discipline, contributed in some way to the experience of continuity. In order to trace such advantages, it is important to understand the historical background to the careers of the respondents interviewed for this study. They had, in most cases, been part of the rapid expansion of higher education which took place in the 1960s and 1970s (Halsey, 2004; Schwartzman \& Balbachevsky, 1997). Many provided accounts of the extent of the changes experienced over the duration of their careers. For individuals who started their working lives in higher education, advantages began to accumulate from an early stage of their entry into academic life. Alvaro described how his doctorate, in a leading European university, still influences his scholarship in retirement. 
The fact that you are abroad, you establish an international network of contacts, and you continue with that. (...) Then professionally you get introduced to this reality and end up being much requested. (...) Every month I send articles there, I receive articles here, in a way, I have a very intense intellectual life (Alvaro, Professor, retired 5 years, Brazil)

However, it was developments in mid-career, and the years preceding retirement, that were perceived to have had a more direct influence on the experience of continuity from work to retirement. The way these developed were specific to each individual set of circumstances but were could be altered or magnified by external events such as organisational change:

I'd reached retirement, so I retired, or was going to retire at the end of three years, but it coincided with the change of Vice Chancellor, and the new Vice Chancellor didn't want too many senior people changing... (...) So, I was asked to stay on as Dean, which I did for almost another two years. (Ronald, Professor, retired 5 years, UK)

Leadership positions brought individuals greater visibility, inside as well as outside of their institutions. In many cases, this led to opportunities before (e.g. Professorial title), and following retirement (e.g. Emeritus Professor title or visiting roles), as well as invitations to be part of discipline-related societies, associations or other roles in their communities (boards of trustees, charities). Lucio, who held two university-level senior leadership university roles for over 8 years, explained the relationship had continued into retirement:

[since retirement] I am called to be part of a panel to state exams [staff recruitment], to be part of a panel of examiners of master and doctorate thesis. (Lucio, Professor, retired 3 years, Brazil) 
For some individuals, in both countries, as their career progressed into the management of programmes, schools and university leadership in some cases, research became a less important aspect of their careers:

As an associate dean, I was responsible eventually for all executive education and all postgraduate programmes as well as teaching, which meant, in a sense, towards the end my research just disappeared because I was too busy doing all of that. (Daniel, Professor, retired 2 years, UK)

Achievement of a prestigious position, despite reduced opportunities for research, still gave individuals in leadership roles sufficient advantage to secure access to formal and semiformal positions following retirement. Research-related advantages, such as a track record in securing research funding or publishing in high ranking journals, also offered benefits in terms of acquiring formal opportunities following retirement. The recurrence and timing (Ferraro \& Morton, 2018) of these were particularly important. Mark, for example, explained how he was asked to delay retirement before being offered a formal fellowship position in retirement:

They asked me to stay on an extra year and a month. And they asked me that because the papers that I had published are in very prestigious journals and they are doing something called the RAE [Research Assessment Exercise] (...) they want to show that you are an internationally acclaimed scientist. (Mark, Senior Lecturer, retired 2 years, UK)

Likewise, in Brazil, Manoel was encouraged to apply for an Emeritus position which he eventually secured following several research related achievements just before retirement:

It is funny, now that I don't want anything to do with this, there was a book, I published a book, there were two recent articles in journals, scientific publications [chuckles], and 
this research is getting the funding approved, which is a bit ironic. (Manoel, Professor, retired 1 year, Brazil)

Scholarship activities, such as reading, writing and reviewing, can potentially provide continuity even without formal links to a university (beyond access to library facilities). However, the nature of the discipline was also seen to influence how these activities could be performed independently of their former institution. Some respondents, for example, referred to difficulties given lack of access to equipment or laboratories. Jose, whose research focuses on a technical area of physics, questioned whether he would be able to continue with his writing if he were to lose his affiliation with the university.

Writing books? So, I go do something more intellectual [in retirement], but this is also a complicated decision - you are going to write about what in this technical area? How many people are interested [referring to non-academic audiences]? (Jose, Adjunct Professor, retired 2 years, Brazil)

Individuals who had a greater teaching focus could still find formal continuity. However, this was not necessarily an advantage by itself but a consequence of an early retirement deal, linked to their pension scheme rules. Robin, who moved to a fractional contract after retirement, explained:

I didn't want to stop now because it's too abrupt. I gradually reduced the amount of administrative responsibilities that I had and still continued really with more or less the same teaching load, so that made life just that little bit easier and what I'm doing now makes it even easier (Robin, Senior Lecturer, retired 2 years, UK)

These examples illustrate the extent to which academics had transferrable skills which could be used to engage in other activities, with many respondents still giving occasional talks or lectures in their area of expertise. Some of these would be in former institutions, conferences 
and societies, or even in unusual places venues such as cruise ships, offering talks to a lay audience. Discipline-specific knowledge in areas such as law and accounting was also regarded as an advantage in enabling continuity in professional practice, with evidence to suggest that individuals felt that they had a wider choice of work activities, combining both traditional academic and professional practice:

I stopped teaching and kept only my activities as a lawyer, this is my legal professionalpractice. My activities as a lawyer today are almost exclusively legal opinions. (Mauro, Adjunct retired 5 years, Brazil)

\section{Desire for Continuity}

The majority of respondents expressed an intrinsic motivation to continue working, consistent with previous research on retired academic (Bragança, 2004; Tizard, 2004). Many of the respondents described their career as a vocation, a passion, or part of a legacy contributing to a better world - whether through teaching or research. In Brazil, respondents reported feeling attached to the institutions which they had helped to build during their tenure. Antonio explained:

When you are committed to the university, when you develop that relationship with the university, you do not want to leave. I don't want to leave and feel committed to stay even at my 69 years of age. (Antonio, Adjunct retired 4 years, Brazil)

In contrast, Gary, became disillusioned both with the way in which his university was managed and how the changes in higher education (in the UK) affected his job. This made him look for other sources of identity in the years before retirement: 
So, the job wasn't what it was. I wasn't enjoying it. I just drew a line under it, and that was very strange because for many years I'd thought and said that a university lecturer wasn't something I did. It was what I was. (Gary, Senior Lecturer, retired 6years, UK)

Despite interpreting his situation as a complete break from his academic career since retirement, Gary had contributed to a book as well as continuing his subscription to a higher education magazine. For most participants, continuity in retirement was partially shaped by their occupational identity, preferred roles, together with the desire to pursue other interests outside work. Robert described his expectation of continuity as follows:

I'm still interested in all academic work, I'm still interested in developments and I'll still research in terms of things I'm teaching, but I'm not going to get involved in any major new projects. I'm certainly not going to write any books or anything, not at this stage. (Robert, Senior Lecturer, retired 2 years, UK)

For some individuals, continuity was a matter of maintaining reading, writing or reviewing activities as part of their routine. Lucio emphasised that his life did not change much following retirement, implying that certain activities are part of his life regardless of the job:

I am like, still involved in the activities such as reading, writing what I like very much, but no longer teach. (Lucio, Professor, retired 3 years, Brazil)

The majority of participants expressed a desire to keep up with developments in their fields, with the freedom to not read or publish academic papers. However, some individuals who had intended to increase their writing in retirement, found that for various reasons this did not materialise:

It would be nice to ... it hasn't worked out quite like that, but nice to go back to ... I did have it in my mind, to go back to more academic work, more research, but time was filled with other things. (Alan, Professor, retired 18 months, UK) 
Health status was an important factor influencing the degree of continuity from work to retirement. Individuals who considered their health to be 'good' or 'very good', expressed frustration that after a certain age employment opportunities would disappear or become limited. This frustration was especially true for individuals who had not attained a professorial position, and were unable to secure an emeritus title. For most, social and physical age-related changes were not something that could be overturned. Physically demanding activities, such as regular teaching, were viewed as unsustainable over the long term:

I decided that I would like to limit my teaching career because I think it's a young man and young woman's business. The older you get the tougher it is, like all forms of teaching, as you get older, it gets harder. I loved doing it, but I thought, I'll bring this to an end so I can carry on doing the other aspects of my career, which was writing, travelling, researching, talking about my interests in a broad sense, not merely to undergraduates. (Joseph, Professor, retired 3 years, UK)

Most of the men had the privilege of formal or informal opportunities for a phased (i.e., gradual) retirement. When talking about their daily routine, nearly all participants indicated that there was a natural and welcomed slowing down of activities over time:

I think that's the difference, it's a change of pace, but I think you adjust to that and you almost lost it, you don't feel as if you've got a lot more time, but you have. (Robert, Senior Lecturer, retired 2years, UK)

Once faced with discontinuities that could not be reversed through re-employment, contract work or due to health issues, individuals tended to accept a narrower range of activities and opportunities for continuity: Alvaro rationalised that these discontinuities were for the best: 
I retired at the compulsory age; otherwise I would have carried on (...) I think I wouldn't have coped, unless it was only once a week. (...) So, I think it was better to retire really (Alvaro, Adjunct Professor, retired 5 years, Brazil)

Continuity of employment was not necessarily needed on the financial side, even participants who mentioned a reduction in income acknowledged that the impact was on nonessential aspects of life. Occupational-related activities that could provide a sense of continuity varied widely from being regular and generally remunerated (e.g. for individuals in employment and those with emeritus positions), to being episodic, and not necessarily remunerated, including minor volunteer roles related to their discipline, former institution, or social and informal meetings or correspondence with former colleagues and students:

I always visit the university (...) I never really left the university. I've got many friends there...[I was] 40 years there; my ex-students are in the administration of the university. So... we have a lot to talk about. (Cesar, Professor, retired 6 years, Brazil)

\section{Discussion}

This study has explored the experience of continuity in the transition to retirement of male academics in Brazil and the UK, with particular attention to the influence of cumulative processes emerging from their biographical narratives (Schafer et al., 2011). The findings suggest that the experience of continuity is almost certainly more complex than that originally envisioned by Atchley (1989). Continuity will experienced differently by each person, but can also be influenced by a combination of varying social factors and individual responses.

In our study, individuals with greater occupational visibility had more opportunities for continuity, linked to what had been high status roles (Tizard \& Owen, 2001). Objectively, this visibility was associated with formal leadership positions, and prestigious job titles, which put individuals in a position of status and advantage both inside and outside of the institution: 
a finding which held for both countries, and which may be viewed as illustrative of Merton's Matthew effect $(1968,1988)$. Coming from a practice-oriented discipline, such as law or finance, was also an advantage that led to a greater scope for continuity in retirement.

Organisational policy and practices, such as encouraging re-employment for early retirees or having formal academic titles or roles for retired academics, were particularly important in determining whether the advantage of 'visibility' could lead to formal continuity in retirement. Such formalised positions in retirement are typically conducive of cumulative processes because they are restricted to a selected number of individuals (Dannefer, 2018). That is, they position some people in positions of privilege over others. When considering the experience of continuity in retirement, these positions are not only an advantage in their own right, but also an outcome of a trajectory of advantage that will continue to accumulate over time. Hence, access to continuity in retirement is far from equal. This finding is particularly important when considering that the respondents in this study already possess many advantages, not only in relation to their occupation, but also insofar as they were already an ideal type (Weber, 1904/2012) within academia: male, white, and with an uninterrupted career. Within the academy, women and people from racially and ethnically diverse backgrounds are underrepresented, especially in senior positions (Catalyst, 2020; University and College Union, 2013; 2019), indicating that they do not enjoy the same linear trajectory of advantage in their careers and are unlikely to have the same opportunities in retirement as the individuals studied for this research.

While retiring male academics generally experienced continuity, perhaps linked to the self-initiated nature of academic activities, most did not draw attention to the impact of discontinuities. This is consistent with the idea that continuity is not sameness, but instead involves a gradual level of change over time (Atchley, 1989; 1999). In our study, many of the activities individuals chose to pursue in retirement tended to relate to the most defining aspects 
of their identity as academics (Taylor, 1999), those roles which participants found more pleasurable (Atchley, 1989; Baltes, 1997), or better represented their career accomplishments. It may be argued that cumulative processes associated with externally assigned labels, in combination with systemic factors, affect how individuals construct their professional identities (Dannefer, 2018). Hence, in addition to influencing objective opportunities for continuity, cumulative processes also shape how individuals view themselves, and make decisions about what is relevant for them. Ferraro and his colleagues (see Ferraro \& Morton, 2018; Ferraro \& Shippee, 2009) highlight the importance of considering the influence of agency on structure, implying that agency enables individuals to actively change patterns of inequality derived from cumulative processes. In this study, however, individual actions shaping their experience of continuity, were still a continuation of advantages (e.g. having access to an emeritus position). Hence, this study supports the idea that agency is not only limited by, but also co-constructed by, systemic forces and structures (Dannefer, 2018). This is a departure from Atchley's constructivist perspective, which requires further investigation.

Subjective perceptions of health may correlate with the individuals' desire to continue working or exit the labour force (Brown \& Vickerstaff, 2011). Similar narratives around health and fitness levels emerged in this study, and this is especially true in relation to regular teaching activities. This demonstrates that the rewards of holding certain roles during one's career are not necessarily a guarantee of continuity in retirement. Health-related factors, even in what Atchley (1989) calls normal ageing, can still hinder the continuity of activities, supporting critics of the theory (Achenbaum, 2009). These differences in health and fitness selfevaluations contribute to cumulative processes determining the individuals' experience of continuity - supporting Ferraro and Morton's (2018) argument that understanding behaviours and responses of individuals are necessary to fully understand differences in late life. 
This study has a number of limitations which should be highlighted. The sample focused on a specific group of retirees, many of whom were drawn from senior positions within the academic profession. Moreover, the study excluded women who tend to experience considerably more disadvantages including career breaks, competing demands from caring roles, slower progression and lower pensions. Participants were primarily recruited through snowball sampling, so individuals who were no longer in touch with academia, former colleagues or in an alumni list, might not have had the chance to be included in the research. Therefore, important patterns of discontinuity might have been missed. The complexity of the topic itself and the task of bringing together theories with diverging assumptions, including subjective and objective aspects, makes it difficult for it to be thoroughly examined in a crosssectional single method study. Further investigations should consider integrating multiplemethods and longitudinal designs to expand our findings.

\section{Conclusions}

This study indicates that while continuity theory (Atchley, 1989; 1999) aids understanding of the transition to retirement, it fails to account for the influence of systemic and related factors influencing the life course. The article highlights limitations with continuity theory in its application to transitions such as those associated with work and retirement. The consideration of how cumulative processes shape career trajectories, personal constructs, and identities, adds an important dimension to our understanding of factors influencing adjustment in later life. Future studies should explore CAD principles in the transition to retirement for other occupational groups (Taylor, 1999). Such research should also examine the experiences of women and minority ethnic groups in their respective transitions from academic careers. Men were in fact the dominant group in the expansion of higher education from the 1960s onwards. Women and minority groups, in contrast, experience systematic discrimination in trying to enter academic life and in applying both for tenure and promotion to senior positions. A key 
issue for future research would be examining the impact of such discrimination, both over the life course and on the type of transitions associated with those from work to retirement.

\section{Acknowledgements}

The authors of this article are grateful to the editor and anonymous referees for their feedback and constructive comments on earlier versions of this paper. 


\section{References}

Achenbaum, W. A. (2009). A Metahistorical Perspective on Theories of Aging' In Bengtson, V. et al. (ed). Theories of Aging. Springer Publishing Company. New York. 25-38.

Atchley, R. C. (1989). A Continuity Theory of Normal Aging. The Gerontologist, 29, 2, 183 90. https://doi.org/10.1093/geront/29.2.183

Atchley, R. C. (1999). Continuity and Adaptation in Aging: Creating Positive Experiences. Baltimore. MD. The Johns Hopkins University Press.

Atchley, R. C. (2000). Social Forces and Aging: An Introduction to Social Gerontology, 9th Edition. Cincinnati: Wadsworth Publishing Company.

Atkinson, A.B. (2015). Inequality: What can be done? Cambridge, Mass: Harvard University Press

Baltes, P. B. (1997). On the incomplete architecture of human ontogeny: selection, optimization and compensation as foundation of developmental theory. American Psychologist 52, 366-80. https://doi.org/10.1037/0003-066X.52.4.366

Beard, R. L., \& Williamson, J. B. (2016). Frames matter: Aging policies and social disparities. Public Policy and Aging Report, 26, 48-52. doi:10.1093/ppar/prw002

Boyatzis, R. (1998). Transforming qualitative information. California, USA: Sage Publications Ltd.

Bragança, A. B. de S. (2004). Aposentadoria: a experiência de professors aposentados do Instituto de Biologia da Unicamp. [Retirement: the experience of retired professors from the Biology institute of Unicamp] Dissertação de Mestrado em Gerontologia. Campinas, SP. Programa de Pós-Graduação em Gerontologia da Unicamp. Brasil.

Brandstädler, J., \& Greve, W. (1994). The aging self: stabilizing and protective processes. Development Review, 14, 52-80. https://doi.org/10.1006/drev.1994.1003 
Braun, V., \& V. Clarke. (2006). Using Thematic Analysis in Psychology. Qualitative research in psychology, 3, 77-101 https://doi.org/10.1191/1478088706qp063oa

Brooks, A. (1997). Academic women. Buckingham [England] ; Bristol, Pa: Society for Research into Higher Education and Open University Press

Brown, P., \& Vickerstaff, S. (2011). Health Subjectivities and Labor Market Participation: Pessimism and Older Workers' Attitudes and Narratives around Retirement in the United Kingdom. Research on Aging, 33, 5, 529-50. https://doi.org/10.1177/0164027511410249

Cahill, M., Pettigrew, J., Robinson, K., \& Galvin, R. (2019). The transition to retirement experiences of academics in "higher education": A meta-ethnography. The Gerontologist, 59(3), e177-e195. doi:10.1093/geront/gnx206

Catalyst (2020). Quick Take: Women in Academia (January 23, 2020). Available at URL: https://www.catalyst.org/research/women-in-academia/

Creswell, J. W. (2013). Research design: Qualitative, Quantitative, and Mixed Methods Approaches. Thousand Oaks, London and New Delhi: SAGE Publications.

Collini, S. (2012). What are universities for? Ed. Penguin books.

Crystal, S., Shea, D. G., \& Reyes, A. M. (2017). Cumulative advantage, cumulative disadvantage, and evolving patterns of late-life inequality. The Gerontologist, 57(5), 910-920. doi:10.1093/geront/gnw056

Damman, M., Henkens, K., \& Kalmijn, M. (2015). Missing work after retirement: The role of life histories in the retirement adjustment process. The Gerontologist, 55(5), 802-813. doi:10.1093/geront/gnt169

Dannefer, D. (2003). Cumulative Advantage and the Life Course: Cross-Fertilizing Age and Social Science Knowledge. Journal of Gerontology 58b: 327-S337.

https://doi.org/10.1093/geronb/58.6.S327 
Dannefer, D. (2018). Systemic and reflexive: Foundations of cumulative Dis/Advantage and life-course processes. The Journals of Gerontology. Series B, Psychological Sciences and Social Sciences, https://doi.org/10.1093/geronb/gby118

Danson, M., \& Gilmore, K. (2012). Employability and flexible retirement: Variations in academia in an age of austerity. Geoforum, 43, Themed issue: Spatialities of Ageing, 1323-32. Disney, R., \& Whitehouse, E. (2003). Cross-national comparisons of retirement income. In S. Crystal \& D. Shea (Eds.), Annual review of gerontology and geriatrics: Vol. 22. Focus on economic outcomes in later life (pp. 60-94). New York: Springer.

Earl, C., \& Taylor, P. (2017) Reconceptualising work-retirement transitions: Critiques of the new retirement and bridge employment, In I. Aaltio, A. Mills, \& J. H. Mills, (eds), Ageing, organizations and management: Constructive discourses and critical perspectives, Palgrave. Ekerdt, D.J. \& DeViney, S. (1990). On defining persons as retired. Journal of Aging Studies, 4, 211-229. https://doi.org/10.1016/0890-4065(90)90023-2

European Commission (2012). She Figures 2012. Statistics and Indicators on Gender Equality in Science. Luxembourg: Office for Official Publications of the European Communities, European Commission.

Ferraro, K. F., \& Morton, P. M. (2018). What do we mean by accumulation? advancing conceptual precision for a core idea in gerontology. The Journals of Gerontology: Series B, 73(2), 269-278. doi:10.1093/geronb/gbv094

Ferraro, K. F., \& Shippee, T. P. (2009). Aging and cumulative inequality: How does inequality get under the skin? The Gerontologist, 49, 333-343.

https://doi.org/10.1093/geront/gnp034

Field, J., Burke, R. J., \& Cooper, C. L. (2013) The Aging Workforce: Individual, Organizational and Societal Opportunities and Challenges In J. Field, R. J. Burke, \& C. L. Cooper (eds). The SAGE handbook of aging, work and society. London ; Thousand Oaks, 
Calif : SAGE. Chapter 1

Halsey, A. H. (2004). Decline of Donnish Dominion: The British Academic Professions in the Twentieth Century. Oxford University Press.

Hollway, W., \& Jefferson, T. (2000). Doing qualitative research differently: free association, narrative and the interview method. Sage publications.

https://doi.org/10.4135/9781849209007

Katz, S. (2020) Precarious life, human development and the life course: critical intersections.

In Grenier, A., Phillipson, C. \& Settersten, R. (eds) Precarity and Ageing: Understanding insecurity and risk in later life. Bristol: Policy Press, 41-68

Kelly, G. (1955). The psychology of personal constructs. Vol. I, II. Norton, New York Kelly, G. (1980). A psychology of the optimal man. In . A.W. Landfield, \& L. M. Leitner (eds) Personal Construct Psychology: Psychotherapy and Personality, ed, pp.18-35. New York: Wiley

Kohli, M., \& Rein, M. (1991). The changing balance of work and retirement. In M. Kohli, , M. Rein, A-M. Guillemard, \& H. van Gunsteren, Time for Retirement: Comparative studies of early exit from the labour force, Cambridge:Cambridge University Press, 1-35.

Künemund, H., \& Kolland, F. (2007). Work and retirement. In Bond, J. et al. (eds). Ageing in Society: European Perspectives on Gerontology. Sage Publications. 167-185.

https://doi.org/10.4135/9781446278918.n8

Lain, D., Airey, L., Loretto, W. \& Vickerstaff, S. (2020) Older workers and ontological precarity: between precarious employment, precarious welfare and precarious households. In Grenier, A., Phillipson, C. \& Settersten, R. (eds) Percarity and Ageing: Understanding insecurity and risk in later life. Bristol: Policy Press, 69-90

Merton, R. K. (1968). The Matthew Effect in science: The reward and communication system of science. Science, 199, 55-63. https://doi.org/10.1126/science.159.3810.56 
Merton, R. K. (1988). The Matthew effect in science, II: Cumulative advantage and the symbolism of intellectual property. Isis, 79, 606-623. doi:10.1086/354848 https://doi.org/10.1086/354848

Moen, P. (1996) A life course perspective on retirement, gender and well-being. Journal of Occupational Health Psychology 1, 2, pp/ 131-144.

https://doi.org/10.1037/1076-8998.1.2.131

Morrow, S. L. (2005). Quality and trustworthiness in qualitative research in counseling psychology. Journal of Counseling Psychology, 52(2), 250-260.

https://doi.org/10.1037/0022-0167.52.2.250

Ní Léime, Á (2017) Older women public sector workers in Ireland: decisions about retirement timing. Journal of Women \& Aging 29(5): 392-404.

Phillipson, C. (2002). Transitions from work to retirement. Bristol: The Policy Press for the Joseph Rowntree Foundation.

Phillipson, C. (2013). Ageing. Cambridge: Policy Press

Phillipson, C. (2019). 'Fuller' or 'extended' working lives?: Critical perspectives on changing transitions from work to retirement. Ageing and Society, 39(3), 629-650.

doi:10.1017/S0144686X18000016

Riessman, C. (1993). Narrative analysis. California, USA: SAGE Publications Ltd Roberts, B. (2002). Biographical research. Buckingham: Open University Press Rosenthal, G. (2005). Biographical research. In Seale, C., Gobo, G., Gubriium, J. \& Silverman, D. (eds.). Qualitative research practice. Sage publications. 48-64. Schafer, M. H., Ferraro, K. F., \& Mustillo, S. A. (2011). Children of misfortune: Early adversity and cumulative inequality in perceived life trajectories. American Journal of Sociology, 116(4), 10531091 
Schwartzman, S. and Balbachevsky, E. (1997). The Academic Profession in Brazil. In Altabach, P. G. (ed.). The International Academic Profession: Portraits from 14 Countries. Princeton, NY: Carnegie Foundation for Advancement of Teaching. Schwartzman, S. (1998). Higher Education in Brazil: The Stakeholders. LCSHD Paper Series. Department of Human Development. The World Bank: Latin America and the Caribbean Regional Office.

Sugar, J. A., Pruitt, K., Anstee, J. L., \& Harris, S. G. (2005). Academic administrators and faculty retirement in a new era. Educational Gerontology, 31, 405-418.

doi:10.1080/03601270590921672

Taylor, P. (1999). Making Sense of Academic Life. The Society for Research into Higher Education \& Open University Press. Buckingham Thody, A. (2011). Emeritus professors in an English University: How is the wisdom of the aged used? Studies in Higher Education, 36, 6, 621-53. https://doi.org/10.1080/03075079.2010.488721

Tizard, B. (2004). Support for retired academic staff: university policies and practices. Oxford Review of Education, 30, 2, 257-63. https://doi.org/10.1080/0305498042000215557 Tizard, B., \& Owen, C. (2001). Activities and Attitudes of Retired University Staff. Oxford Review of Education, 27, 2, 253-70. https://doi.org/10.1080/03054980123355 University and College Union (2013). The Position of Women and BME Staff in Professorial Roles in UK HEIS. UCU publications. Available from URL:

https://www.ucu.org.uk/bmewomenreport University and College Union (2019). Black academic staff face double whammy in promotion and pay stakes. Available from URL: https://www.ucu.org.uk/article/10360/Black-academic-staff-face-double-whammy-inpromotion-and-pay-stakes 
Veiga, I. P. A. (2007). Docentes Universitários Aposentados: ativos ou inativos? [Retired university faculty: active or inactive?]. Brasilia, Brazil: Junqueira \& Marin

Vickerstaff, S., \& J. Cox. (2005). Retirement and risk: the individualisation of retirement experiences? The Sociological Review. 53, no 1: 77-95.

https://doi.org/10.1111/j.1467-954X.2005.00504.X

von Bonsdorff, M., \& Ilmarinen, J. (2012). Continuity Theory and Retirement. In: Wang, M. (Ed.), The Oxford Handbook of Retirement. Oxford University Press.

https://doi.org/10.1093/oxfordhb/9780199746521.013.0039

Wang, M., \& Shultz, K. S. (2010). Employee retirement: A review and recommendations for future investigation. Journal of Management, 36, 172-206.

https://doi.org/10.1177/0149206309347957

Weber, M. (2012). The “objectivity” of knowledge in social science and social policy. In:

Weber, M. (ed.) Collected Methodological Essays (ed HH. Bruun \& Whimster; trans. HH Bruun). London: Routledge, 100-138. (Original work published 1904)

Wildman, J. M. (2019). Life-Course Influences on Extended Working: Experiences of Women in a UK Baby-Boom Birth Cohort. Work, Employment and Society. https://doi.org/10.1177/0950017019880077 Whitbourne, S. K. (1986). The me I know: A study of adult identity. N.Y.: Springer-Verlag. https://doi.org/10.1007/978-1-4613-8618-6 
Table 01: Sample

\begin{tabular}{|c|c|c|c|}
\hline Participant & Age & $\begin{array}{l}\text { Discipline } \\
\text { sector }\end{array}$ & Description \\
\hline $\begin{array}{l}\text { Alberto } \\
\text { (Brazil) }\end{array}$ & 67 & STEM & $\begin{array}{l}\text { Retired } 2 \text { years, still employed by the university but reduced } \\
\text { activities. Holds a research grant. No longer does any extra } \\
\text { teaching outside his institution. }\end{array}$ \\
\hline $\begin{array}{l}\text { Alvaro } \\
\text { (Brazil) }\end{array}$ & 75 & Humanities & $\begin{array}{l}\text { Retired } 5 \text { years at compulsory retirement age. Still actively } \\
\text { engaged in his area of scholarship internationally - } \\
\text { reviewing papers and giving talks on his area of } \\
\text { scholarship. }\end{array}$ \\
\hline $\begin{array}{l}\text { Antonio } \\
\text { (Brazil) }\end{array}$ & 69 & $\begin{array}{l}\text { Social } \\
\text { Sciences }\end{array}$ & $\begin{array}{l}\text { Retired } 4 \text { years and employed with a fractional contract at } \\
\text { a different institution. Holds a volunteer position at his } \\
\text { former university. }\end{array}$ \\
\hline $\begin{array}{l}\text { Cesar } \\
\text { (Brazil) }\end{array}$ & 76 & STEM & $\begin{array}{l}\text { Retired at compulsory retirement age } 6 \text { years ago. Held a } \\
\text { volunteer position at his former university for } 4 \text { years } \\
\text { following retirement. Keeps in touch with former } \\
\text { colleagues. }\end{array}$ \\
\hline $\begin{array}{l}\text { Jose } \\
\text { (Brazil) }\end{array}$ & 67 & STEM & $\begin{array}{l}\text { Retired } 2 \text { years and still employed. Mainly involved in } \\
\text { technical activities and research. Holds a science research } \\
\text { grant. }\end{array}$ \\
\hline $\begin{array}{l}\text { Hugo } \\
\text { (Brazil) }\end{array}$ & 56 & STEM & $\begin{array}{l}\text { Retired } 3 \text { years. Took retirement because he feared pension } \\
\text { reforms would affect his entitlement. Still employed. Holds } \\
\text { a department-level leadership position and holds a } \\
\text { research grant. }\end{array}$ \\
\hline
\end{tabular}




\begin{tabular}{|c|c|c|c|}
\hline $\begin{array}{l}\text { Lucio } \\
\text { (Brazil) }\end{array}$ & 73 & Humanities & $\begin{array}{l}\text { Retired at compulsory retirement age } 3 \text { years ago. } \\
\text { Formerly in university senior leadership. Still pursues his } \\
\text { scholarship, writes books and gives talks on his area of } \\
\text { scholarship. }\end{array}$ \\
\hline $\begin{array}{l}\text { Manoel } \\
\text { (Brazil) }\end{array}$ & 71 & $\begin{array}{l}\text { Social } \\
\text { Sciences }\end{array}$ & $\begin{array}{l}\text { Retired at compulsory age } 1 \text { year ago. Formerly in school- } \\
\text { level leadership. Has an active role at his former university } \\
\text { and still holds research grants. Was awarded an Emeritus } \\
\text { Professor position. }\end{array}$ \\
\hline $\begin{array}{l}\text { Mauro } \\
\text { (Brazil) }\end{array}$ & 75 & Humanities & $\begin{array}{l}\text { Retired at compulsory retirement age } 5 \text { years ago. Still } \\
\text { involved in activities related to the practice of his } \\
\text { discipline. }\end{array}$ \\
\hline $\begin{array}{l}\text { Roberto } \\
\text { (Brazil) }\end{array}$ & 70 & STEM & $\begin{array}{l}\text { Retired } 5 \text { years and still employed. Holds a school-level } \\
\text { leadership position, but is reaching the compulsory age of } \\
70 \text { years old. Six months following the interview he was } \\
\text { made an Emeritus Professor. }\end{array}$ \\
\hline $\operatorname{Alan}(U K)$ & 64 & Humanities & $\begin{array}{l}\text { Retired } 18 \text { months. Formerly in university senior } \\
\text { leadership, Emeritus Professor. Still gives talks and is } \\
\text { involved in activities using his managerial skills. }\end{array}$ \\
\hline $\begin{array}{l}\text { Daniel } \\
(U K)\end{array}$ & 67 & $\begin{array}{l}\text { Social } \\
\text { Sciences }\end{array}$ & $\begin{array}{l}\text { Retired } 2 \text { years. Formerly in school-level senior leadership. } \\
\text { Still involved in activities using his managerial skills and } \\
\text { the practice of his discipline. }\end{array}$ \\
\hline $\operatorname{Mark}(U K)$ & 68 & STEM & $\begin{array}{l}\text { Retired } 2 \text { years after being asked to delay retirement for a } \\
\text { year. Still has an active role at his former university and } \\
\text { gives talks on his area of scholarship. Was made an } \\
\text { Honorary Fellow. Strong publications pre-retirement. }\end{array}$ \\
\hline
\end{tabular}




\begin{tabular}{|c|c|c|c|}
\hline $\operatorname{Gary}(U K)$ & 64 & Humanities & $\begin{array}{l}\text { Took early retirement } 6 \text { years ago and left the university } \\
\text { completely. Wrote a few articles on his area of scholarship. }\end{array}$ \\
\hline $\operatorname{Colin}(U K)$ & 66 & STEM & $\begin{array}{l}\text { Retired } 3 \text { years. Left the university to pursue research } \\
\text { commercially. Still involved with his former university and } \\
\text { was made an Emeritus Professor }\end{array}$ \\
\hline $\begin{array}{l}\text { Joseph } \\
(U K)\end{array}$ & 66 & Humanities & $\begin{array}{l}\text { Went part-time } 6 \text { years ago and retired completely } 3 \text { years } \\
\text { ago. Still researches, writes and gives talks on his area of } \\
\text { scholarship. Was made an Emeritus Professor. }\end{array}$ \\
\hline $\begin{array}{l}\text { Mathew } \\
(U K)\end{array}$ & 62 & Humanities & $\begin{array}{l}\text { Retired } 2 \text { years ago and continues in a } 0.6 \text { contract } \\
\text { employment. Still involved with school-level senior } \\
\text { leadership, teaching and scholarship }\end{array}$ \\
\hline $\begin{array}{l}\text { Robert } \\
(U K)\end{array}$ & 62 & STEM & $\begin{array}{l}\text { Retired } 2 \text { years ago and continues in a } 0.6 \text { contract } \\
\text { employment. Formerly in programme-level leadership, now } \\
\text { focuses on teaching activities. }\end{array}$ \\
\hline $\operatorname{Robin}(U K)$ & 62 & $\begin{array}{l}\text { Social } \\
\text { Sciences }\end{array}$ & $\begin{array}{l}\text { Retired } 2 \text { years ago and continues in a } 0.6 \text { contract } \\
\text { employment. Now focuses on teaching activities. }\end{array}$ \\
\hline $\begin{array}{l}\text { Ronald } \\
(U K)\end{array}$ & 70 & STEM & $\begin{array}{l}\text { Retired } 5 \text { years ago but was asked to continue part-time for } \\
\text { another } 2 \text { years to assist with senior leadership changes. } \\
\text { Formerly in school-level senior leadership. Was made an } \\
\text { Emeritus Professor and Foundation Fellow. Still has an } \\
\text { active role at his former university. }\end{array}$ \\
\hline
\end{tabular}

